\title{
Examining Dimensions of Halal Tourism Attributes and Tourist Experience to Enhance Destination Image in Lombok
}

\author{
Natia Humairah* andYeshika Alversia \\ Universitas Indonesia, Indonesia
}

\begin{abstract}
Halal tourism is currently widely applied to meet the needs of Muslim tourists and increase the interest and number of tourists to visit by several countries. This study examines the influences of halal tourism attributes and tourist's travel experience on destination image. More specifically, this study aims to identify the role of each dimensions of halal tourism attributes and travel experience in enhancing destination image to further provide innovation on the services provided by management. Five dimensions of halal tourism attributes (social environment, facilities, food \& beverages, service, and staff), four dimensions of travel experience (escapism, entertainment, esthetics, and education), and four dimensions of destination image (scenery, infrastructure, affective, and water sports) were identified from previous studies. Data were collected by distributing self-administered online questionnaire to 330 respondents who have visited Lombok in the last two years. Structural equation modelling was used to analyze the data using PLS-SEM to examine the impact of dimensions and variables that influence destination image. The results show that both halal tourism attributes (HTA) and travel experience (TE) positively influence destination image (DI), with TE has the stronger impact on DI. Partial least squares regression analysis shows that from all the dimensions of TE, entertainment and escapism have the strongest influence, while for HTA, food \& beverages and facilities have biggest value in developing halal friendly attributes. Meanwhile, from all the dimensions of DI, the affective dimension shows the biggest value. The results show that tourist experience together with halal tourism factors can positively affect the destination image of Lombok. Therefore, to be able to innovate on the services provided in this tourism sector, managers can focus on developing halal friendly attributes while keep entertaining the tourists to develop positive destination image.
\end{abstract}

Keywords: Destination image; halal tourism attributes; tourist experience; tourism marketing; innovation

\section{Introduction}

Given the current technological advances, the travel between regions and continents has become a lot easier. In addition to a highly developed transportation system, the emergence of online ticketing and hotel booking applications has also made travel planning more practical because it can be done anywhere. The activities of the tourism industry have contributed $7 \%$ to the exporting of goods and services on a world export scale and it was ranked third after energy and food products in Indonesia's export commodity ranking. Tourism is one of the biggest contributors to Indonesia's income. The local governments have been the right to regulate and manage the development and management of their tourist areas themselves. This is in order to encourage the community to play an active role in competing in today's global market.

Over time, the development of tourism encourages public interest. One of the associated developments is halal tourism. Halal tourism is the concept that where tourist attractions provide Muslims with the ability to act within Islamic religious law when carrying out their tourism activities, such as restaurants with a halal certificate, easily finding mosques and places to pray, facilities that distinguish between men and women such as swimming pools and the gym, and others (Battour et al., 2016). Halal tourism is not only applied by countries with a Muslim population but also by non-Muslim tourist destination countries such as Singapore, Thailand, England, 
Japan, South Korea and others. This country has implemented a halal tourism system because the biggest contributor to foreign exchange for tourists is Muslims, specifically those from Indonesia.

The Global Muslim Travel Index (GMTI) is an assessment of halal tourism destinations based on four criteria: access (access to air, land, sea and road infrastructure) up to 10\%, communication (guidance for Muslim visitors, education for stakeholders, ease of reaching markets, tour guides and digital marketing) up to $15 \%$, the environment (domestic and international), tourist arrivals, Wi-Fi coverage at the airport, commitment to halal tourism) up to $30 \%$, and services (halal restaurants, mosques, airports, hotels and attractions) up to $45 \%$. Studies conducted on the Muslim market will continue to grow rapidly in the Asian region which is estimated to reach a value of US $\$ 300$ billion in 2026 with an estimated growth of $9.1 \%$ annually. GMTI 2019 has projected that by 2030, the number of Muslim tourists worldwide will reach 230 million people. Indonesia is ranked first in the world for halal tourism based on the GMTI assessment in 2019. Lombok is ranked first for halal tourism based on the Indonesia Muslim Travel Index (IMTI), also won the "Best Halal and Honeymoon Destination" in Abu Dhabi in 2016. The number of foreign tourists coming to Indonesia has increased by almost $22 \%$ and the number of tourists of Lombok increased by $50 \%$ after promoting halal tourism destinations in 2017. Currently, Lombok is the first area to have a Regional Regulation for halal tourism formulated by the NTB DPRD and a leader in Muslim friendly services and facilities with more than a thousand mosques. There are quite a number of halal-certified restaurants and a large number of prayer rooms available. Lombok has one hotel that complies with Sharia law, 60 hotels with halal-certified kitchens and several tourist guides who can speak Arabic. Lombok also has a strong commitment to continuing to make Lombok a destination for halal tourism in a sustainable manner.

By further strengthening the branding and image of halal tourism, this is not only in order to attract foreign tourists but also to attract tourists from within their own country, especially millennials who have a high visiting intention (Salsabila, 2019). Currently, the religious level of millennial Muslims is categorised as high. This affects them when determining the tourist attractions to visit. Increasing the image of halal and the city itself is done not only to attract international tourists but also to attract tourists from within the country. Based on the above background, the researcher wants to know the influence and effectiveness of the halal tourism attributes and the tourist experience on the destination image of the tourist destinations in Lombok.

\section{Literature Review}

\section{Destination Image}

The destination image perceived by tourists plays an important role in decision-making, in the choice of tourist destinations, in the evaluation after the visit, in terms of future behaviour and in the intention to revisit (Chen and Tsai, 2007). A person's perception of the image of a tourist destination can affect the intention to make a visit or satisfaction which gives a positive experience after a visit (Beerli and Martin, 2004). According to AlAnsi, et al (2019), the overall picture of the destination plays an important role in tourism marketing to increase attracting more international arrivals. The image of the destination greatly affects the loyalty of tourists to a destination. In addition, the image of Halal Tourism in the destination makes a positive contribution to attracting first-time tourists and has an important relationship with their future interests and desires. High quality halal products and services, such as food, facilities and environment, will reduce feelings of anxiety and enhance the image for Muslim tourists. In Assaker's (2014) research, an empirical test of the destination image model was derived theoretically where the second order was formed by the first-order construction studied directly. This is called the second order. The hierarchical model is considered more profitable because it provides a broader destination image construction.

Based on the research by Assaker (2014) regarding the dimension of destination image taking into account several previous studies, it was concluded that it has several dimensions, namely general functional attributes (price, climate and type of accommodation), special functional attributes (tourist attractions and cultural festivals that only exist in the tourist destination) and psychological attributes (friendliness of the population, the 
beauty of the scenery, and the feelings felt when visiting the tourist attractions). These dimensions were developed again to obtain six goal attributes for the first factor, namely famous natural attractions, various tourist and cultural services, the quality of the atmosphere of the tourist spot, entertainment and recreation, the environment in general, and accessibility.

\section{Push and Pull Motivations}

The push-pull theory framework is a popular theory used to explain the reasons why tourists decide to visit a specific destination rather than another destination, the types of experience that they want to get and the types of activities they want to do (Prayag and Hosany, 2014). Push factors are the things that underlie and direct a person's behaviour to travel. Push motivation is thought to shape the desire to travel, referring to the need to escape from everyday surroundings for the purpose of relaxation, discovering new things, new places and people. Social interactions and the enhancement of kinship relationships act as dominant driving motive in holiday decisions. Conversely, the pull motivation explains the actual choice of goals, including factors such as scenic tourist attractions, historical sites, and others (Bindu and Kanagaraj, 2013). Motivation is understood to be an underlying force that directly and indirectly affects behaviour. Motivation arises when someone wants to fulfil their needs. The driving factor is the socio-psychological visitor contract which affects their motivation to visit a tourist attraction (peace, loneliness, experiencing new experiences etc.). The pull factor refers to the quality of the arrangement that attracts them to come to a particular tourist object or destination (Beh and Bruyere, 2007).

\section{Halal-Friendly Attributes}

Several studies have defined the conceptual meaning of halal tourism, its practices and various aspects in the hospitality and tourism industry. Jafari and Scott (2014) explained certain Islamic facts that provide an important understanding of increasing the awareness among international destinations about understanding the needs of Muslim tourists and developing strategic plans to attract segments in this market. An empirical study by Olya and Al-Ansi (2018) articulated the concept of halal and haram in the context of tourism and showed that Muslim tourists understand the various types of risk related to the consumption of related halal products and services. The availability of halal food, prayer rooms, a place free from haram food and alcohol as well as separate male and female facilities are some of the halal characteristics that must be fulfilled according to Islamic law (Battour, Battor and Bhatti, 2014). Stephenson (2014) created the classification of two dimensions (tangible and intangible) which form the elements of halal hospitality. For example, the principles of halal tourism cover a variety of services in the hospitality industry such as human resource management (staff uniforms and ethics), marketing, promotion and other public facilities (no gambling, casinos and nightclubs). The provision of various services and halal products has become a necessity in areas where Muslim tourists usually visit (airports, hotels, shopping centres, restaurants and others).

As a result, halal tourism has become important as the country has started to lure tourists using Muslim-friendly attractions while offering competitive prices, promotions and services. Halal tourism plays an important role as it allows Muslim tourists to enjoy their holidays without prejudice regarding their religious requirements and obligations during their trip. The provision of various halal services and products has become a necessity in areas that have a large number of Muslim tourists.

H1: Halal friendly attributes positively influence destination image

\section{Tourist Experience}

A tourist is a first-time or repeat visitor to a destination and this is very important to distinguish between when assessing the image of the destination and the associated consequences, especially the intention to revisit and provide references. More previous trips will create a better image of the destination and a stronger desire and willingness to revisit the same destination (Chi, 2012). Tourists who have travel experience with a specific 
destination may feel more familiar and have a bond with the tourist destination than those who have limited travel experience, so their cognitive assessment of the destination will be different (Tosun et al., 2015).

The literature has frequently shown that the tourist experience is directly associated with revisiting (Kim et al., 2012). The experience of tourism also influences the image of the destination (Beerli and Martin, 2004; Kim et al., 2012). This is a complex mixture of products, services and attributes woven into a total impression. The image attributes are often classified as cognitive (individual beliefs and attitudes about a goal) and affective (feelings, i.e. the emotions that can be evoked by the tourist destination) attributes (Beerli and Martin, 2004), with cognitive images contributing to affective images (Sonmez and Sirakaya, 2002). Experience therefore does not influence the revisiting intention through goal images. Research has shown that the goal images contributes to the revisiting intentions (Kim et al., 2012; Zhang et al., 2014)

$\mathrm{H} 2$ : Tourist experience positively influences the destination image.

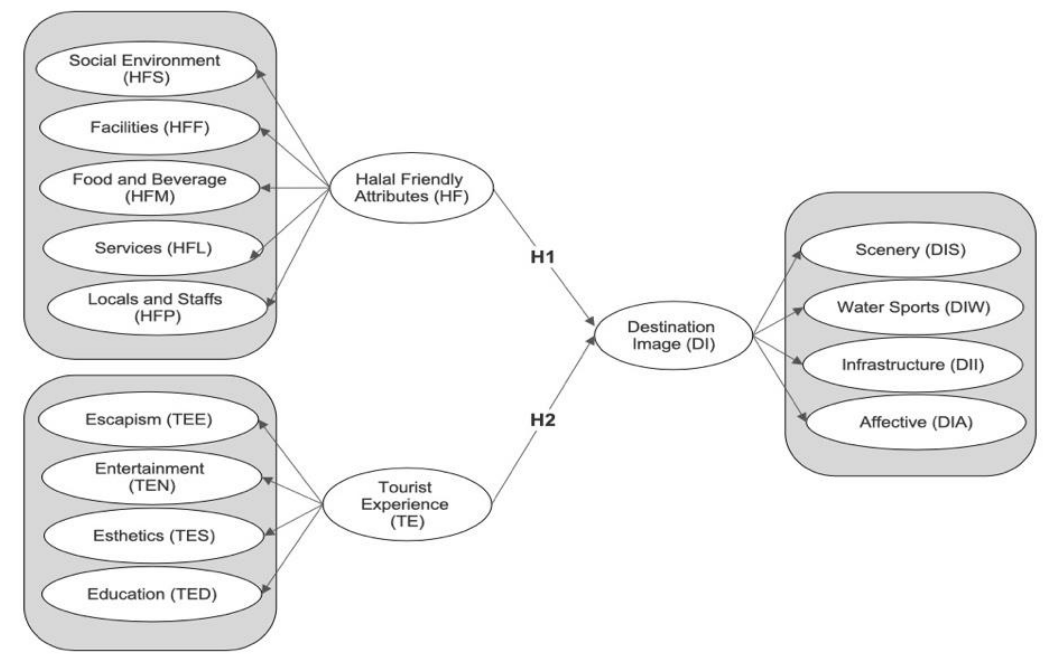

Figure 1. Research Model

\section{Methods}

This study used Lombok Island, a popular vacation destination in East Nusa Tenggara, Indonesia as the destination object. Lombok offers beautiful sea locations and unique island tourism. Many tourists visit the island of Lombok for a leisurely vacation. The survey respondents were a group of domestic tourists who had visited Lombok at least once in the past two years. Based on the previous research by Tan (2017) and Al-Ansi et al (2019), we have summarised the list of common image attributes. This process produced a final list of thirteen constructs as shown in Table 1. 
Table 1. Constructs

\begin{tabular}{|c|c|}
\hline Construct & Items \\
\hline Halal Friendly & Design and decoration of halal-friendly tourist attractions \\
\hline Attributes & The atmosphere of tourist attractions that comply with \\
\hline Halal-friendly Social & Islamic rules \\
\hline \multirow[t]{5}{*}{ Environment (HFS) } & $\begin{array}{l}\text { I feel comfortable with the social environment in a halal- } \\
\text { friendly tourist spot }\end{array}$ \\
\hline & $\begin{array}{l}\text { I have a good experience at a tourist place with a halal } \\
\text { friendly social environment }\end{array}$ \\
\hline & The environment in tourist attractions is free from haram \\
\hline & $\begin{array}{l}\text { The environment in the tourist attractions is clean and safe } \\
\text { for Muslim tourists }\end{array}$ \\
\hline & I enjoy a halal-friendly environment at a tourist attraction \\
\hline \multirow[t]{4}{*}{$\begin{array}{l}\text { Halal-friendly } \\
\text { facilities (HFF) }\end{array}$} & $\begin{array}{l}\text { In general, it is easier to access places of worship / prayer } \\
\text { rooms }\end{array}$ \\
\hline & $\begin{array}{l}\text { Halal-friendly facilities are offered in many tourist } \\
\text { attractions }\end{array}$ \\
\hline & $\begin{array}{l}\text { At certain tourist sites, separate facilities are provided for } \\
\text { women and men }\end{array}$ \\
\hline & $\begin{array}{l}\text { There is a separate prayer room for women and men at } \\
\text { tourist attractions }\end{array}$ \\
\hline \multirow[t]{4}{*}{$\begin{array}{l}\text { Halal Food and } \\
\text { Beverages (HFM) }\end{array}$} & $\begin{array}{l}\text { Food outlets / restaurants at tourist sites display the halal } \\
\text { logo }\end{array}$ \\
\hline & Food and drinks served are clean, safe and hygienic \\
\hline & Food providers in halal accredited tourist sites \\
\hline & $\begin{array}{l}\text { The easy availability of halal food attracts me to visit tourist } \\
\text { attractions }\end{array}$ \\
\hline \multirow[t]{4}{*}{$\begin{array}{l}\text { Halal-friendly service } \\
\text { (HFL) }\end{array}$} & $\begin{array}{l}\text { Information relating to halal services is easy to find at tourist } \\
\text { attractions }\end{array}$ \\
\hline & Tourist information center offers halal service information \\
\hline & $\begin{array}{l}\text { Halal services at tourist sites are effectively explained in } \\
\text { several languages }\end{array}$ \\
\hline & $\begin{array}{l}\text { Halal services are offered at tourist attractions in accordance } \\
\text { with Islamic law }\end{array}$ \\
\hline \multirow[t]{3}{*}{$\begin{array}{l}\text { Residents and Staff } \\
\text { (HFP) }\end{array}$} & $\begin{array}{l}\text { Local staff at tourist sites are aware of halal products and } \\
\text { services }\end{array}$ \\
\hline & Local staff offer halal-friendly services \\
\hline & $\begin{array}{l}\text { In general, locals have a good understanding of Islamic and } \\
\text { halal rules }\end{array}$ \\
\hline
\end{tabular}

The purposive sampling technique was used to collect data from 330 domestic Muslim respondents age 17 and above. They were not Lombok residents. The data collection was conducted for one month from April to May 2020. The study items were measured using a 6-point Likert scale ranging from 1 (strongly disagree) to 6 (strongly agree). The reason for using a 6-point Likert scale was in order to provide the participants with a variety of choices to show get a more accurate response. The questionnaire was in English and then translated into Indonesian using the method of blind translation. This survey consisted of three parts. Part one introduces the purpose of the survey and includes brief instructions on the anonymity of respondents and the confidentiality of responses. Section two contains the demographic profiles of the participants including gender, age, level of education, and religion. The last part involves the survey questions in order to measure the main variables of the research model.

Data analysis was performed to determine the results of the survey. From these results, the researcher can interpret and describe the results of the data. In this study, two stages of data testing and analysis will be carried 
out. The first stage is a pre-test of 30 respondents using the IBM SPSS Statistics 25 software to determine the validity and reliability of the measurements used.

The second stage is the data analysis in order to find out the results of the research conducted. The method used in this study was Structural Equation Modelling (SEM) with SmartPLS because the data in this study is not normally distributed. The Structural Equation Modelling (SEM) method is a continuation of path analysis and multiple regression which is a form of multivariate analysis. The SEM method is considered to be better because it can analyse data more comprehensively by combining factor analysis and path analysis (Haryono, 2017). The regression analysis, factor analysis and path analysis involved in the collective analysis of the survey data can cause biases when faced with the underlying theory. This is because the use of the analysis technique does not involve measurement errors and latent variables in the measurement model or structural model. Because SEM is covariant-based, it must be based on existing concepts and theories. It is then to be confirmed by the research sample. This requires many assumptions being made such as the samples being large (the ratio between the observed variables and the sample is 1:10), the normality of the data and the complexity of the model. Partial Least Square is the best solution because it does not require assumptions like in LISREL/AMOS. (Kurniawan and Yamin, 2009). SEM with variance-based PLS that is not accommodated in SEM-based covariance (LISREL) has the special characteristic of a reflective indicator, whereas variance-based SEM (PLS) can involve reflective or formative indicators (Wijayanto, 2008).

\section{Results}

Based on the results of the previous tests, the existing model meets the requirements for the further testing of the hypothesis. Hypothesis testing was carried out on the models that have been subjected to verification by removing the indicators that are inadequate, invalid and unreliable. After the validity and reliability of the main test was conducted, the halal-friendly attributes variable has five dimensions, namely social environment (HFS), facilities (HFF), food and drinks (HFM), services (HFL) and residents and staff (HFP). The five variables are explained using twenty-two initial indicators. The tourist experience variable has four dimensions: escapism (TEE), entertainment (TEN), aesthetics (TES) and education (TED). The four variables are explained using fourteen indicators. The destination image variable has four dimensions: scenery (DIS), water sports (DIW), infrastructure (DII) and affective (DIA). The four variables are explained using fifteen initial indicators

Convergent validity is the value of the loading factor on a latent variable with its indicators. The expected value for an instrument if it is valid is $>0.5$ (Hair et al, 2009). The following Table shows loading factor value for each indicator that has been verified. 
Table 2. SLF Main Test Value

\begin{tabular}{|c|c|c|c|c|c|c|c|}
\hline \multirow[t]{2}{*}{ Indicator } & \multicolumn{6}{|c|}{ Standardized Loading Factor } & \multirow[t]{2}{*}{ Output } \\
\hline & HFS & $\mathrm{HFF}$ & HFM & HFL & $\mathrm{HFP}$ & $\mathrm{HF}$ & \\
\hline HFS1 & 0.673 & & & & & & Valid \\
\hline HFS2 & 0.735 & & & & & & Valid \\
\hline HFS3 & 0.774 & & & & & & Valid \\
\hline HFS4 & 0.784 & & & & & & Valid \\
\hline HFS5 & 0.638 & & & & & & \\
\hline HFS6 & 0.761 & & & & & & Valid \\
\hline HFS7 & 0.828 & & & & & & Valid \\
\hline HFF1 & & 0.839 & & & & & Valid \\
\hline HFF2 & & 0.872 & & & & & Valid \\
\hline HFF3 & & 0.689 & & & & & \\
\hline HFF4 & & 0.712 & & & & & Valid \\
\hline HFM1 & & & 0.859 & & & & Valid \\
\hline HFM2 & & & 0.829 & & & & Valid \\
\hline HFM3 & & & 0.849 & & & & Valid \\
\hline HFM4 & & & 0.766 & & & & Valid \\
\hline HFL 1 & & & & 0.888 & & & Valid \\
\hline HFL2 & & & & 0.892 & & & Valid \\
\hline HFL3 & & & & 0.832 & & & \\
\hline HFL4 & & & & 0.857 & & & Valid \\
\hline HFP1 & & & & & 0.920 & & \\
\hline HFP2 & & & & & 0.915 & & Valid \\
\hline HFP3 & & & & & 0.847 & & Valid \\
\hline HFS & & & & & & 0.864 & Valid \\
\hline $\mathrm{HFF}$ & & & & & & 0.879 & Valid \\
\hline HFM & & & & & & 0.879 & Valid \\
\hline HFL & & & & & & 0.850 & Valid \\
\hline HFP & & & & & & 0.809 & Valid \\
\hline & TEE & TEN & TES & TED & & $\mathrm{TE}$ & \\
\hline TEE1 & 0.819 & & & & & & Valid \\
\hline TEE2 & 0.899 & & & & & & Valid \\
\hline TEE3 & 0.784 & & & & & & Valid \\
\hline TEE4 & 0.872 & & & & & & Valid \\
\hline TEN1 & & 0.857 & & & & & Valid \\
\hline TEN2 & & 0.889 & & & & & Valid \\
\hline TEN3 & & 0.902 & & & & & Valid \\
\hline TEN4 & & 0.912 & & & & & Valid \\
\hline TES1 & & & 0.920 & & & & Valid \\
\hline TES2 & & & 0.899 & & & & Valid \\
\hline TES3 & & & 0.906 & & & & Valid \\
\hline TED1 & & & & 0.877 & & & Valid \\
\hline TED2 & & & & 0.927 & & & Valid \\
\hline TED3 & & & & 0.880 & & & Valid \\
\hline TEE & & & & & & 0.640 & Valid \\
\hline TEN & & & & & & 0.906 & Valid \\
\hline TES & & & & & & 0.893 & Valid \\
\hline TED & & & & & & 0.818 & Valid \\
\hline
\end{tabular}




\begin{tabular}{|c|c|c|c|c|c|c|}
\hline & DIS & DIW & DII & DIA & DI & \\
\hline DIS1 & 0.567 & & & & & \\
\hline DIS2 & 0.860 & & & & & Valid \\
\hline DIS3 & 0.732 & & & & & Valid \\
\hline DIS4 & 0.749 & & & & & \\
\hline DIS5 & 0.572 & & & & & \\
\hline DIW1 & & 0785 & & & & Valid \\
\hline DIW2 & & 0.822 & & & & Valid \\
\hline DIW3 & & 0.879 & & & & Valid \\
\hline DII1 & & & 0.84 & & & \\
\hline DII4 & & & 0.866 & & & Valid \\
\hline DII5 & & & 0.88 & & & Valid \\
\hline DIA1 & & & & 0.894 & & Valid \\
\hline DIA2 & & & & 0.886 & & Valid \\
\hline DIA3 & & & & 0.845 & & Valid \\
\hline DIA4 & & & & 0.894 & & Valid \\
\hline DIS & & & & & 0.817 & Valid \\
\hline DIW & & & & & 0.795 & Valid \\
\hline DII & & & & & 0.611 & Valid \\
\hline DIA & & & & & 0.885 & Valid \\
\hline
\end{tabular}

Based on the loading factor value in Table 2, all of the loading factor values have met the requirements, which is greater than 0.5. All indicators for the halal-friendly attributes, tourist experience and destination image variables can be explained properly by each indicator. This is also referred to as convergent validity.

Instrument reliability is the level of accuracy or consistency of the research instrument. An instrument is said to be reliable if it has a Composite Reliability $>0.7$ and Cronbach's Alpha $>0.6$ for all constructs (Hussein, 2015). The following table shows the results of the reliability testing that has been carried out using the Smart PLS 3.0 software that has passed the previous specifications. Based on the values in Table 3, all of the values have met the requirements for $\mathrm{CR}>0.7$, and Cronbach's Alpha> 0.6, thus it can be said that the latent variable has high reliability.

Table 3. Cronbach Alpha and CR Main Test Value

\begin{tabular}{cccl} 
& $\begin{array}{c}\text { Cronbach Alpha } \\
(>\mathbf{0 , 6})\end{array}$ & $\begin{array}{c}\text { Composite Reliability } \\
(>\mathbf{0 , 7 )}\end{array}$ & Output \\
\hline HFS & 0.864 & 0.896 & Reliabel \\
\hline HFF & 0.785 & 0.862 & Reliabel \\
\hline HFM & 0.845 & 0.896 & Reliabel \\
\hline HFL & 0.890 & 0.924 & Reliabel \\
\hline HFP & 0.875 & 0.923 & Reliabel \\
\hline TEE & 0.866 & 0.909 & Reliabel \\
\hline TEN & 0.913 & 0.939 & Reliabel \\
\hline TES & 0.894 & 0.896 & Reliabel \\
\hline TED & 0.876 & 0.924 & Reliabel \\
\hline DIS & 0.744 & 0.828 & Reliabel \\
\hline DIW & 0.774 & 0.869 & Reliabel \\
\hline DII & 0.832 & 0.899 & Reliabel \\
\hline DIA & 0.903 & 0.932 & Reliabel \\
\hline HF & 0.948 & 0.953 & Reliabel \\
\hline TE & 0.927 & 0.937 & Reliabel \\
\hline DI & 0.892 & 0.910 & Reliabel \\
\hline
\end{tabular}


The calculations conducted using the Smart PLS 3.0 software. This test uses the value of the path coefficients, taking into account that the value of the t-statistics is more than t-table $>1.96$ and the p-value $<0.05$. If the values meet these two conditions, then the hypothesis can be accepted, indicating that is there is an influence and significance between the variables tested. Whether the influence is positive or negative can be seen in the value of the original sample. If the value is negative, then it means that the existing hypothesis has a negative influence.

Table 4. Structural Model Results and Hypothesis Testing $(N=330)$

\begin{tabular}{cccc}
\hline & Original Sample & T-Statistics & P-Value \\
\hline H1 & 0.115 & 2.898 & 0.004 \\
\hline H2 & 0.718 & 19.018 & 0.000 \\
\hline
\end{tabular}




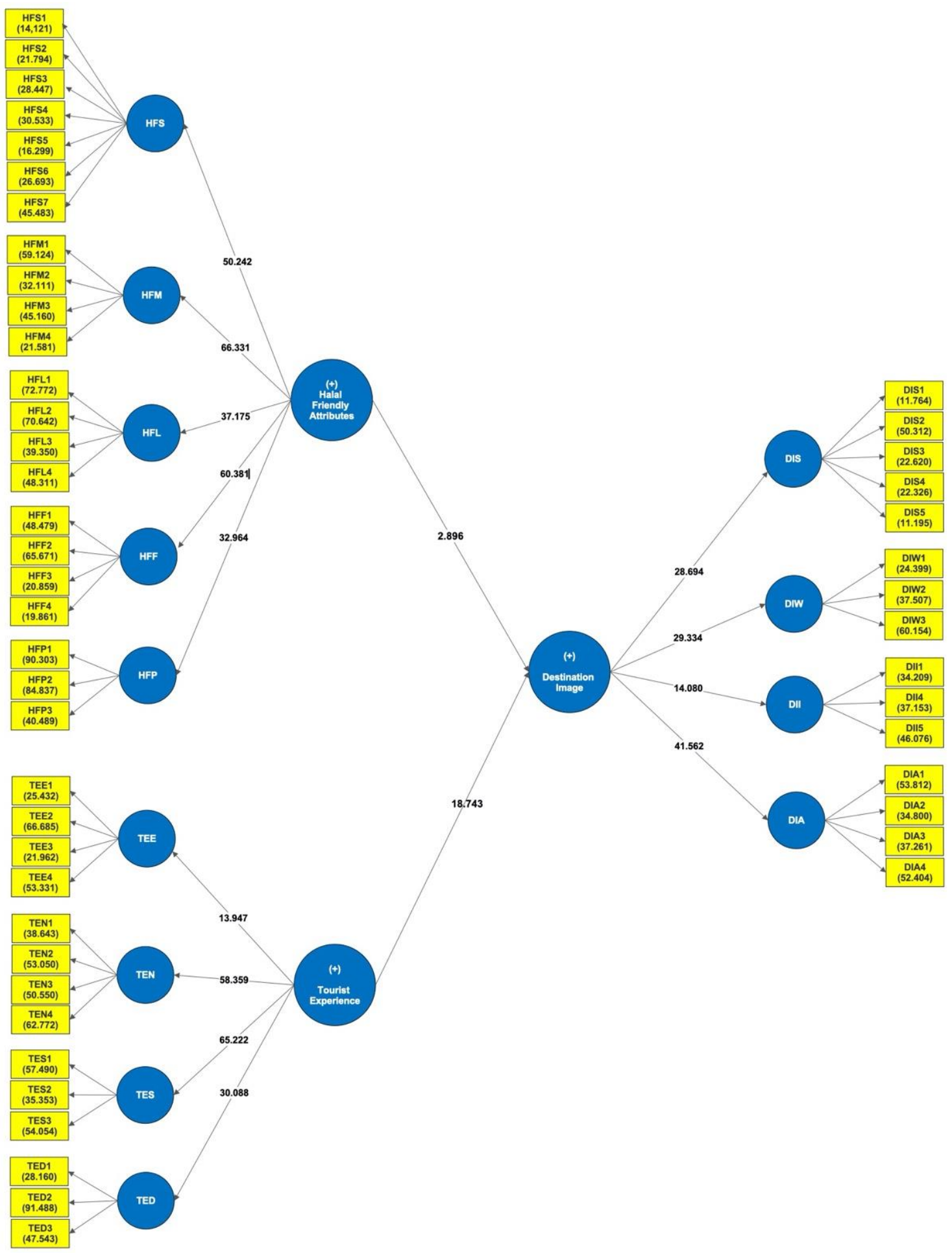

Figure 2. The Structural Model

\section{Discussion}

\section{Dimensions of Halal Friendly Attributes and Tourist Experience}

Based on the PLS results, it can be seen that the influence of Tourist Experience (TE) on Destination Image (18.743) greater than Halal Friendly Attributes (HF) on DI with a value of 2.896. The following is the order of the results of constructs and items in the Halal Friendly Attributes (HF) variable. HFM $(66,331)$ with the highest constructs HFM1 $(59,124)$ and the lowest was HFM4 $(21,581)$, HFF $(60,381)$ with the highest construct was 
HFF2 $(65,671)$ and the lowest was HFF4 $(19,861)$, HFS $(50,242)$ with the highest HFS7 $(45,483)$ and the lowest was HFS1 $(14,121)$, HFL $(37,175)$ with the highest construct HFL1 $(72,772)$ and the lowest HFL3 $(39,350)$, and HFP $(32,964)$ with the highest construct HFP1 $(90,303)$ and the lowest was HFP3 $(40,489)$. Then in the Tourist Experience (TE) variable, TES has the highest value, namely 65,222 with TES1 $(57,490)$ and TES2 $(35,353)$. followed by TEN $(58,359)$ with the highest construct TEN4 $(62,772)$ and the lowest TEN1 $(38,643)$, TED $(30,088)$ with the highest construct TED2 $(91,488)$ and the lowest TED1 $(28,160)$, and TEE $(13,947)$ with the highest construct value TEE2 $(66,685)$ and the lowest TEE3 $(21,962)$. Whereas the Destination Image (DI) variable itself has the highest value is DIA $(41,562)$ with the highest construct is DIA1 of 53,812$)$ and the lowest is DIA2 $(34,800)$, followed by DIW $(29,334)$, DIS $(28,694)$, and finally DII $(14,080)$ with the highest construct value DII5 $(46,076)$ and the lowest was DII1 $(34,209)$.

\section{The Influence of Halal-friendly Attributes on Destination Image}

Hypothesis 1's analysis results show that it has a p-value of 0.004 and a t-statistic value of 2.898. This shows that there is a significant influence due to halal-friendly attributes on the destination image. Paired with looking at the results of the original sample with a positive value $(0.115)$, it can be concluded that Hypothesis 1 is accepted. There is significant positive influence from the halal-friendly attributes present on the destination image which indicates that the higher the halal attributes displayed by Lombok, the higher the good image of Lombok in the eyes of tourists. These results are consistent with the previous studies conducted by Battor et al (2014) and Oktadiana (2016) which explain that halal-friendly attributes have a positive and significant effect on the affective and overall objective destination image. This is increasingly supported by the research by Al-Ansi et al (2019). The most important factor is the availability of halal food and drinks in the tourist destination. This is also supported by the results of this study where the dimension of food and beverages (HFM) had the highest path value compared to the other dimensions at 66.330. Food stalls in the tourist attractions provide a halal certificate' (HFM3) had the highest score of 45.160. Lombok offers many halal-friendly facilities. This could be due to difference in the countries studied and the research respondents where in Indonesia, halal food is easier to obtain because Indonesia itself is a Muslim country. Regardless, it remains the most important dimension.

\section{The Influence of the Tourist Experience on Destination Image}

The results of Hypothesis 2 have a p-value of 0,000 and a t-statistic value of 19.018. This shows that there is a significant influence from the tourist experience on the destination image. As well as looking at the results of the original sample with a positive value (0.718), it can be concluded that Hypothesis 2 is accepted. There is a significant positive influence from the tourist experience on the destination image, indicating that the better the experience of tourists in previous visits, the higher the positive image of Lombok in the eyes of tourists. The tourist experience variable related to destination image has the highest influence value, indicates that this variable has the most influence on the image of the tourist area compared to the other variables. These results are consistent with the previous research by Tan (2017). In the results of this study, the highest value was found in the aesthetics constructs (TES) of 65.222, the respondents were domestic tourists which have a pleasant experience as well as the beauty of the scenery of Lombok which makes the tourists experience exceeds their expectations and get the serenity and pleasure from their previous trip. A memorable travel experience directly affects the image of a tourism destination. This also means that an unforgettable tourism experience will be stored in the memory as an individual subjective evaluation of all tourism experiences that have been carried out (Dagustani et al, 2018).

\section{Managerial Implications, Limitations, and Future Research}

Looking at the results of the t-statistic value in the path diagram, the halal friendly attributes variable for the food and beverages (HFM) has the highest t-statistic / SLF value of 66.330. The lowest score is for the locals and staff at 32.964. The results can be interpreted that although Lombok already has a pleasant image as a halalfriendly tourist destination, this has not had a major impact on Lombok's destination image. 
The following are some of the suggested managerial implications to improve halal tourism and the tourist experience in Lombok. 1) The Tourism Office can organise halal events and seminars in Lombok to educate both tourism industry players and residents about halal needs. The local government also needs to ensure that the business is on target and to ensure that all of the residents of Lombok know about the launch of halal tourism. 2) The provision of proper and easily accessible facilities for worship such as at tourist service centres, shopping centres, health centres, airports, and hotels. Service providers are strongly advised to improve the existing tourism services by offering prayer room facilities for men and women and having the relevant information on the key tourist attractions available to increase the positive impact of the images of both affective and the overall destination. 3) The Tourism Office should ensure that the existing facilities are in good condition and suitable for use, and if necessary, to restructure the building where this is not so. This is so then tourists have a good image of Lombok because it is clean and has modern public facilities. 4) There should be an improvement of the security and infrastructure such as transportation, information centres, health services, shopping facilities, restaurants and hotels while bearing in mind the image of the tourist destination. The improvement of these aspects will require there to be collaboration between all of the stakeholders and support from the government. 5) There should be an improvement in the professionalism of tour operators and travel agents such as tourism packages, outdoor activities, and quality services because this can improve the image of the tourist destinations. 6) The tourism industry players can develop different marketing programs for different groups of tourists (first time tourists versus repeat tourists). This is because activities that are attractive to new tourists may not be suitable to motivate previous tourists to re-visit. For example, the developing programs for tourists should not only focus on price cuts but also encourage greater emotional involvement with the land and water landscape such as nature tours in Lombok.

This study has limitations that are likely to affect the overall research results. These limits are as follows: 1) the respondents who filled out the questionnaires may travel to Lombok because of work matters and not for a vacation. This can affect the results of this research. 2) The next limitation is that we do not know whether the respondent is a first time visitor or a repeat traveller. 3) Last, the income of each respondent can also influence and become a limitation in this study. For further research, all these limitations can be reduced by respondents filling out the screening questions about first time or repeat traveller, income, and vacation purposes before proceed to the main questions.

Based on the implementation and the results obtained from this study, the suggestions that can be given for further study of this research are as follows: 1) explore more dimensions such as personnel / family preferences, culture, art characteristics and the attributes of the events and festivals available for Muslim tourists visiting Lombok, which covers a large aspect of halal-friendly tourism; 2) investigate the Muslim tourist demographics (age, gender, education, income level) on model variables, which can help business developers and marketers in Lombok to develop more effective marketing plans and 3) further research can make international Muslim tourists the respondents in order to be able to get results from research with a wider scope when developing halal tourism in Lombok in accordance with the behaviour of overseas consumers.

\section{Conclusion}

Halal tourism is an emerging market in Indonesia. In order for Lombok tourism authorities and business developers to attract more visitors, this study has identified attributes that will help to raise the overall image and perception of the tourism experience and how they play a defining role in the destination offerings of Lombok. Based on the research results, halal attributes and tourist experience significantly influence the destination image of Lombok Island. The most influential dimension of the halal friendly attribute variable is halal food and beverages (HFM). Halal friendly attributes have a significant and positive effect on the destination image of Lombok with SLF value of 2.898. Tourist experience has a significant and positive effect on the image of the Lombok destination with an SLF value of 19.018. 
PLS analysis shows that Halal Food and Beverage and Aesthetic Experience contribute a defining role to the image of the destination. It is very important to achieve effective goals in the overall image by providing halal food and beverages and maintaining cleanliness and aesthetic in tourist destination. This study also provides a holistic picture of the role of halal attributes and tourist experiences in travel-related activities, shows that halal tourism also has contribute on tourist perceptions to improve halal characteristics in the tourism industry to ensure tourist loyalty and influence to make decisions in choosing their destination.

\section{References}

Al-Ansi, Amr \& Olya, Hossein \& Kim, Wansoo. (2019). Exploring halal-friendly destination attributes in South Korea: Perceptions and behaviors of Muslim travelers toward a non-Muslim destination. Tourism Management.

Assaker, G. (2014). Examining a Hierarchical Model of Australia's Destination Image. Journal of Vacation Marketing, 20(3), 195-210.

Battour, M., \& Ismail, M. N. (2016). Halal tourism: Concepts, practises, challenges and future. Tourism management perspectives, 19, 150-154.

Battour, Mohamed \& Battor, Moustafa \& Bhatti, Muhammad. (2014). Islamic Attributes of Destination: Construct Development and Measurement Validation, and Their Impact on Tourist Satisfaction. International Journal of Tourism Research.

Beerli, A., \& Martin, J. D. (2004). Factors influencing destination image. Annals of Tourism Research, 31, 657681.

Beh, A., \& Bruyere, B.L. (2007) Segmentation by Visitor Motivation in Three Kenyan National Reserves. Tourism Management, 28 (6), 1464-1471.

Bindu, T. \& Kanagaraj, C.. (2013). A study on international tourist's satisfaction with tourism services in Kerala. Life Science Journal, 10, 177-185.

Chen, C. F., \& Tsai, D. C. (2007). How destination image and evaluative factors affect behavioral intention?. Tourism management, 28(4), 1115- 1122

Chi, C.G., \& Qu, H. (2008) Examining The Structural Relationships of Destination Image, Tourist Satisfaction and Destination Loyalty : An Integrated Approach. Tourism Management, Vol. 29(4), 624-636.

Dagustani, D., Kartini, D., Oesman, Y. M., \& Kaltum, U. (2018). Destination Image of Tourist: Effect of Travel Motivation and Memorable Tourism Experience. Etikonomi: Jurnal Ekonomi, Vol. 17 (2), 307 - 318 . doi: http//dx.doi.org/10.15408/ etk.v17i2.7211.

Hair, J. F., Black, W. C., Babin, B. J., \& Anderson, R. E. (2009). Multivariate data analysis (7th ed.). New York: Prentice Hall.

Haryono, Siswoyo. (2017). Metode SEM Untuk Penelitian Manajemen Dengan AMOS LISREL PLS. Luxima Metro Media.

Heesup Han \& Amr Al-Ansi \& Hyeon-Cheol Kim, 2019. "Perceived Inconveniences and Muslim Travelers' Loyalty to Non-Muslim Destinations," Sustainability, MDPI, Open Access Journal, Vol. 11(17), 1-14.

Kurniawan, H., dan Yamin, S. 2009. Structural Equation Modelling: Lebih Mudah Mengolah Data Kuesioner dengan Lisrel dan SmartPLS. Salemba Infotek: Jakarta

Jafari, J., \& Scott, N. (2014). Muslim world and its tourisms. Annals of Tourism Research, 44, 1-19.

Kim, K., Hallab, Z., \& Kim, J. N. (2012). The moderating effect of travel experience in a destination on the relationship between the destination image and the intention to revisit. Journal of Hospitality Marketing Management, 21, 486-505.

Oktadiana, Hera \& Pearce, Philip \& Chon, Kaye. (2016). Muslim travellers' needs: What don't we know?. Tourism Management Perspectives. 20. 124-130. 10.1016/j.tmp.2016.08.004.

Olya, Hossein \& Al-Ansi, Amr. (2018). Risk assessment of halal products and services: Implication for tourism industry. Tourism Management.

Prayag, G., \& Hosany, S. 2014. When Middle East meets West: Understanding the Motives and Perceptions of Young Tourists from United Arab Emirates. Tourism Management, Vol. 40, 35-45. 
Salsabila, N., \& Alversia, Y. (2019). Examining Push-Pull Motivation and Travel Intention for Potential Travelers in Indonesia Using Theory of Planned Behaviour. Tourism Development Centre International Conference.

Sönmez, S. and E. Sirakaya (2002). A Distorted Destination Image? The Case of Turkey. Journal of Travel Research, 41(2), 185-196.

Stephenson, M. L. (2014). Deciphering 'Islamic hospitality': Developments, challenges and opportunities. Tourism Management, 40, 155-164.

Tan, Wee-Kheng. (2017). Repeat visitation: A study from the perspective of leisure constraint, tourist experience, destination images, and experiential familiarity. Journal of Destination Marketing \& Management.

Tosun, C., Dedeoglu, B.B., \& Fyall, A. (2015). Destination Service Quality, Affective Image and Revisit Intention : The Moderating Role of Past Experience. Journal of Destination Marketing and Management, Vol. 4(4), 222-234.

Wijayanto, S.H. (2008). Structural Equation Modeling dengan LISREL 8.8. Yogyakarta: Graha Ilmu

Zhang, Y., \& Peng, Y. (2014). Understanding Travel Motivations of Chinese Tourists Visiting Cairns, Australia. Journal of Hospitality and Tourism management, Vol. 21, 44-53. 